F. Cardigos $\cdot$ F. Tempera $\cdot$ S. Ávila $\cdot$ J. Gonçalves

A. Colaço $\cdot$ R. S. Santos

\title{
Non-indigenous marine species of the Azores
}

Received: 22 June 2005/ Accepted: 4 January 2006/Published online: 17 February 2006

(C) Springer-Verlag and AWI 2006

\begin{abstract}
Marine benthic species introduced to the Azores are collated from scientific publications, internal reports and own data. Twelve algae and 21 invertebrates are classified as non-indigenous species, 18 as cryptogenic. Two species of algae and two ascidians are regarded as particularly invasive along the shores of this oceanic archipelago.
\end{abstract}

Keywords Marine introductions $\cdot$ Non-indigenous species $\cdot$ Azores

\section{Introduction}

As volcanic islands located close to the Mid-Atlantic Ridge (França et al. 2003), the Azores are geologically recent and separated from the nearest continental coasts by at least 1,300 km (Morton et al. 1998). Natural colonization for marine organisms occurs mainly through oceanic currents. At present, the prevailing sea-surface pathway to the Azores is a descending branch from the Gulf Stream running from NW towards SE (Santos et al. 1995). Nevertheless, the major affinities of the autochthonous marine flora and fauna are with the continental coasts of Europe and Africa, the Mediterranean Sea and the other Macaronesian archipelagos of Madeira and Canary islands (Santos et al. 1995; Tittley and Neto 1995; Ávila 2000, 2005). Birds can also be vectors of introductions. This may be the case of the caenogastropod Assiminea sp. found at Praia da Vitória

Communicated by K. Reise

F. Cardigos $(\bowtie) \cdot$ F. Tempera · J. Gonçalves · A. Colaço

R. S. Santos

IMAR, Department of Oceanography and Fisheries, University of the Azores, 9901-862 Horta, Portugal

E-mail: frederico@notes.horta.uac.pt

S. Ávila

Department of Biology and CIRN (Centro de Investigação de Recursos Naturais), University of the Azores, 9501-855 Ponta Delgada, Portugal
(Ávila 2005). Factors conditioning the natural and human-mediated marine colonization of the Azores are discussed by Cornelius (1992) and Morton and Britton (2000). Besides natural pathways, various anthropogenic factors presently concur as additional vectors of entrance for marine species in areas outside their natural biogeographic range (Bax et al. 2003). Of these, hull fouling, ballast water, solid ballast, recreational boating and dive practices, fisheries and aquaria trade may be relevant for the Azores.

Little is known on marine species introductions and invasions to the Azores. However, the potential for introductions is high, considering that the transatlantic leisure boat-traffic stopping over at the islands has significantly increased over the last decade. Scattered literature (Monniot 1971; Monniot C 1974; Monniot F 1974; Cornelius 1992; Wirtz and Martins 1993; Tittley and Neto 1994, 1995; Neto 1997; Morton et al. 1998; Southward 1998; Ávila 2000, 2005; Morton and Britton 2000) together report 51 taxa as exotic marine species for the coastal areas in this NE Atlantic archipelago. The aim of this paper is to provide a commented list of these species, to delete misidentifications, to add new records and to indicate the invasive status.

\section{Methods}

A literature review and a database query were conducted. The "DOP Database" is a computerized species list, which compiles information from 575 SCUBA dives carried out to study assemblages of conspicuous species in the Azores archipelago. During these surveys, species that could not be identified in situ were collected and preserved for later identification. Samples of new records were stored in the Department of Oceanography and Fisheries of the University of the Azores (DOP). The marine mollusc database [Department of Biology of the University of the Azores (DBUA)] of one of the authors (S. Ávila) is also included. The DBUA database contains information on geographic distribution, mode 
of development and other pertinent details of the shallow $(<50 \mathrm{~m})$ marine molluscs of the Azores. The data are based on 880 samples collected in about 660 dives around all of the islands of the Azores. Species with disjunct geographic distributions (e.g., Azores and Mediterranean) as well as those commonly found nearby harbours were studied in detail in order to assess whether their occurrence was natural or human mediated. Planktonic organisms have not been considered.

In the present paper, criteria given by Boudouresque and Verlaque (2002) to consider a species as "introduced" are applied: (1) it colonizes a new area where it was not recorded previously; (2) the extension of its range is linked, directly or indirectly, to human activity; (3) widely disjunct dispersion; (4) new generations of non-native species are produced in situ without human assistance, thus constituting self-sustaining populations. To decide upon the introduction to the Azores, we adapted these criteria: (1) the species is new to the Azores; (2) occurrence in the Azores constitutes a geographic discontinuity to the species' known range; (3) a new occurrence is at first very localized and (4) further spread within the archipelago follows a consistent pattern; (5) the species has established a persisting population. If according to these criteria there are doubts about the introduction status, populations are classified as cryptogenic (sensu Carlton 1996).

\section{Results}

Fifty-five taxa have been pointed as introduced in the Azores (Table 1). Eighteen are now classified as cryptogenic and 33 as established introduced species. Two taxa are rejected: the gastropod Engina turbinella and the crab Carcinus maenas previous records for the Azores are most likely misidentifications. The hydrozoan Ventromma halecioides may not yet be established. Pollia dorbigny is mentioned as an introduced species for the first time. Caulerpa webbiana (introduced) and Bugula cf. dentata (cryptogenic) are mentioned for the first time for the Azores archipelago.

\section{Algae}

Asparagopsis armata is a well-known invasive species that has its origin in the southern hemisphere and was first recorded in the northern hemisphere in 1923 (summarized in Verlaque et al. 2004). This species is widely spread throughout the Azores, in rocky habitats between 0 and $20 \mathrm{~m}$ (DOP Database), displaying a biomass maximum during spring (Neto 1997). Asparagopsis taxiformis is cosmopolitan in warm-temperate to tropical waters (Chualain et al. 2004) and was first recorded for the Azores as $A$. delilei by Schmidt (1931). It was not recorded in the Faial (Tittley and Neto 1994) and Flores islands 1989 expeditions (Neto and Baldwin 1990), Flores 1994/1995 expeditions (Tittley et al. 1998) and Santa Maria 1990 expedition (Neto et al. 1990), where it occurs nowadays. It presently occurs in Santa Maria, São Miguel, Faial, Pico, Flores, and Graciosa islands (DOP Database) and probably São Jorge due to proximity to Pico and Faial. It occupies a depth stratum similar to A. armata and co-occurs with the latter but its niche seems to extend to more sheltered places. According to Tittley and Neto (2005) A. taxiformis is now less common in São Miguel island possibly due to competition with $A$. armata. Contrastingly, unsystematic observations around Faial and Pico seem to show an expansion of the distribution and an increase in the abundance over the last decade. This variation in abundance needs further explanation.

Caulerpa webbiana is an invasive species recently collected in Horta harbour. It has colonized several sites around Horta harbour after its first record in 2002.

Codium fragile tomentosoides is a potentially invasive species for the Azores. It was first recorded by Neto (1997) for São Miguel island and then for Corvo island. Despite its capacity for spreading and replacing the indigenous species elsewhere (Nyberg and Wallentinus 2004), this has not yet been observed in the Azores.

\section{Ascidiacea}

Clavelina oblonga is more widespread in Faial and Pico islands (DOP Database) than C. lepadiformis, but the occurrence of the former is so far limited to those two islands. It covers large areas with hundreds of individuals per $\mathrm{m}^{2}$, especially at vertical and slightly overhanging surfaces. Due to limited distance (in the order of a few tens of $\mathrm{km}$ ) separating the three islands of the "Triangle" and the frequent boat traffic among them, there is a possibility that it may occur at São Jorge as well but no surveys have been done there recently.

Distaplia corolla is invasive in the Azores and is recorded for all the islands, although its abundance is low at Corvo, Flores and Santa Maria islands (DOP Database). The species was probably introduced by sailing yachts (Monniot and Monniot 1983) travelling from the Antilles. It occurs both on well-lit and shaded areas down to $35 \mathrm{~m}$.

\section{Discussion}

The low number of introduced species compared to other areas (e.g., Coles et al. 1999) is probably a consequence of the geographic isolation of the Azores, comparatively low commercial shipping, scarcity of shallow lagoons and absence of marine aquaculture and of estuarine habitats. The low number of scientific studies on the biogeography of Azorean marine species may have also affected the results. As for Bugula cf. dentata and Cinachyrella cf. alloclada, the identification of species is doubtful due to the lack of taxonomic expertise. Molecular work should be conducted in order 


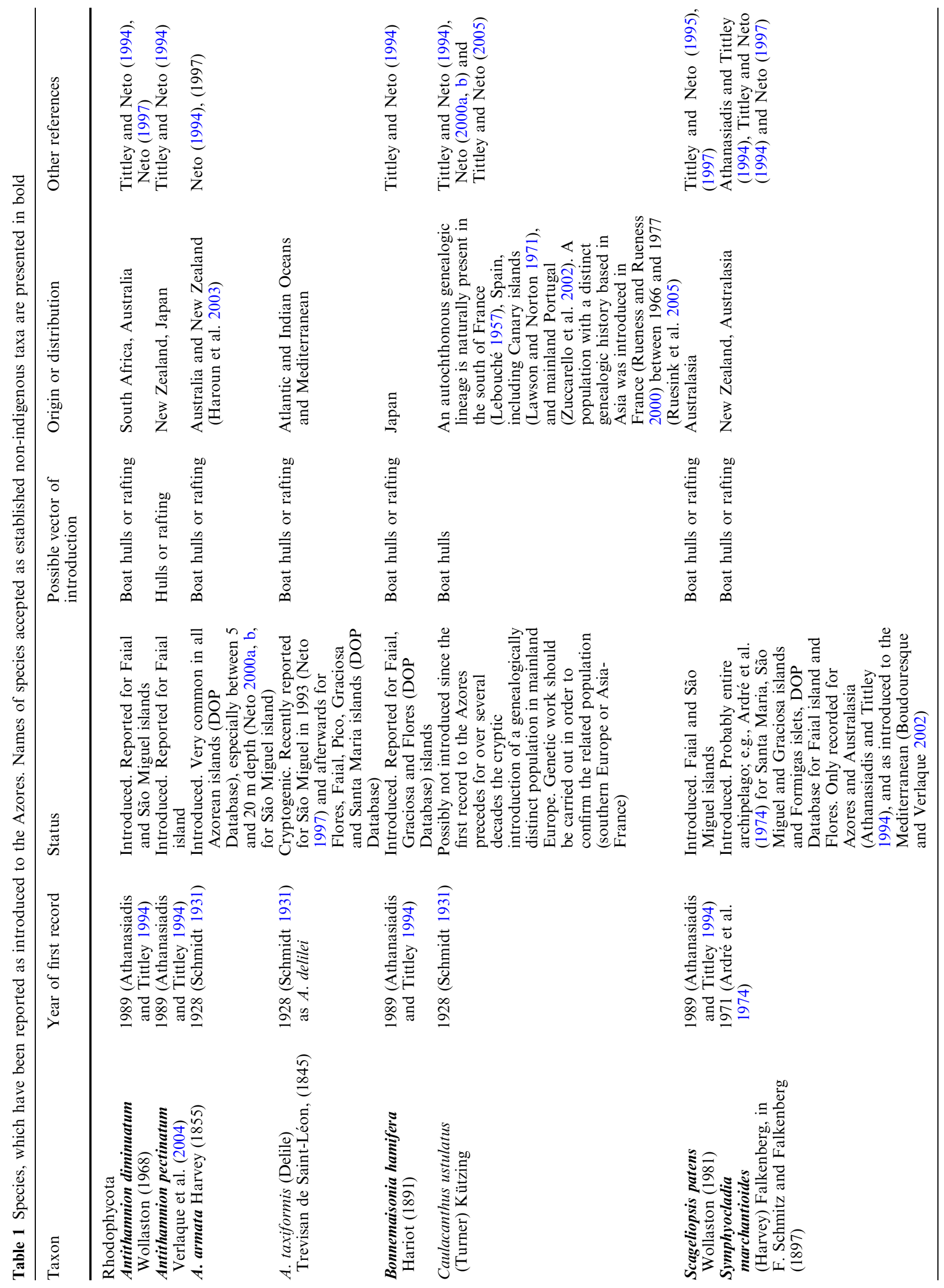




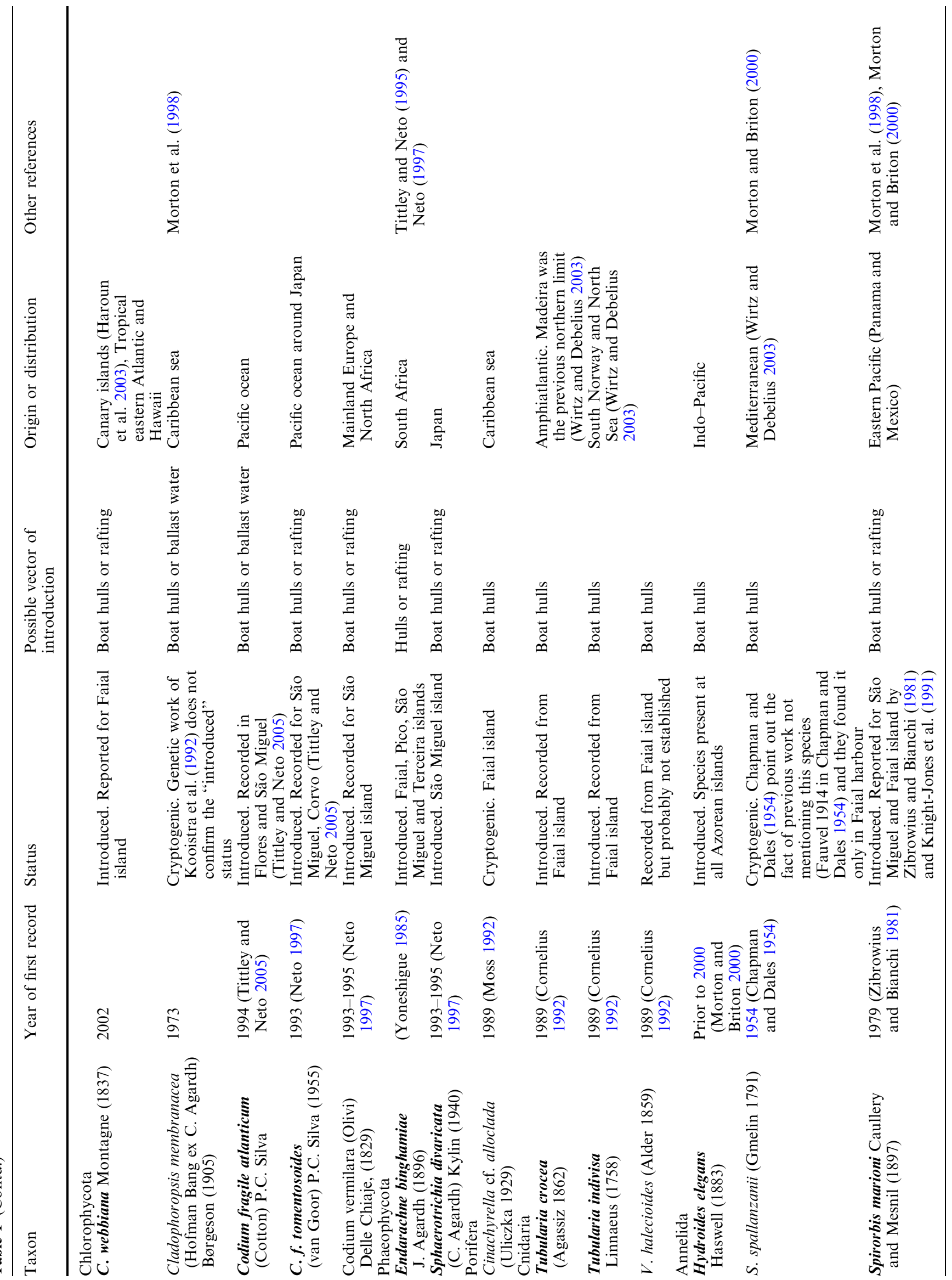




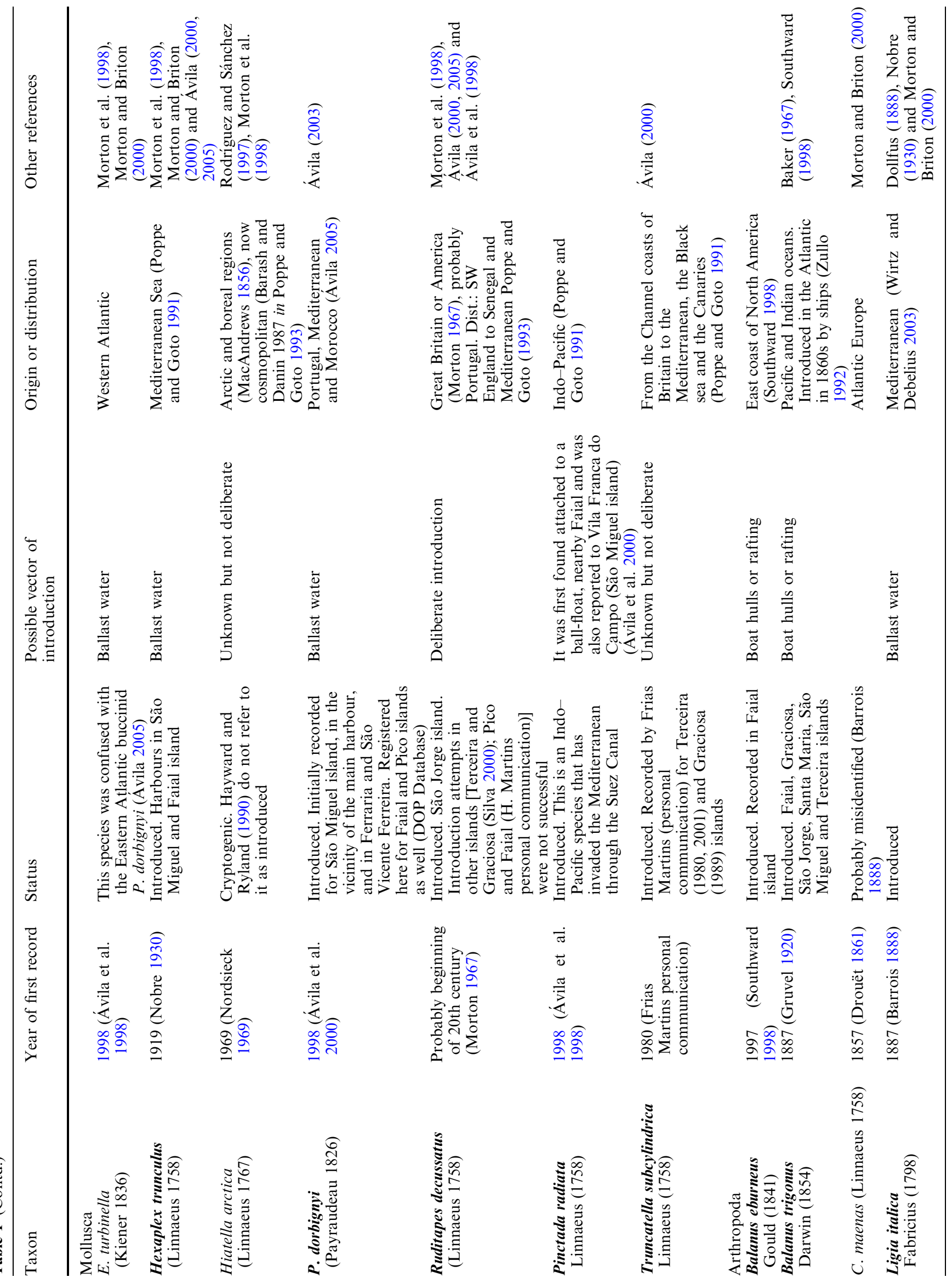




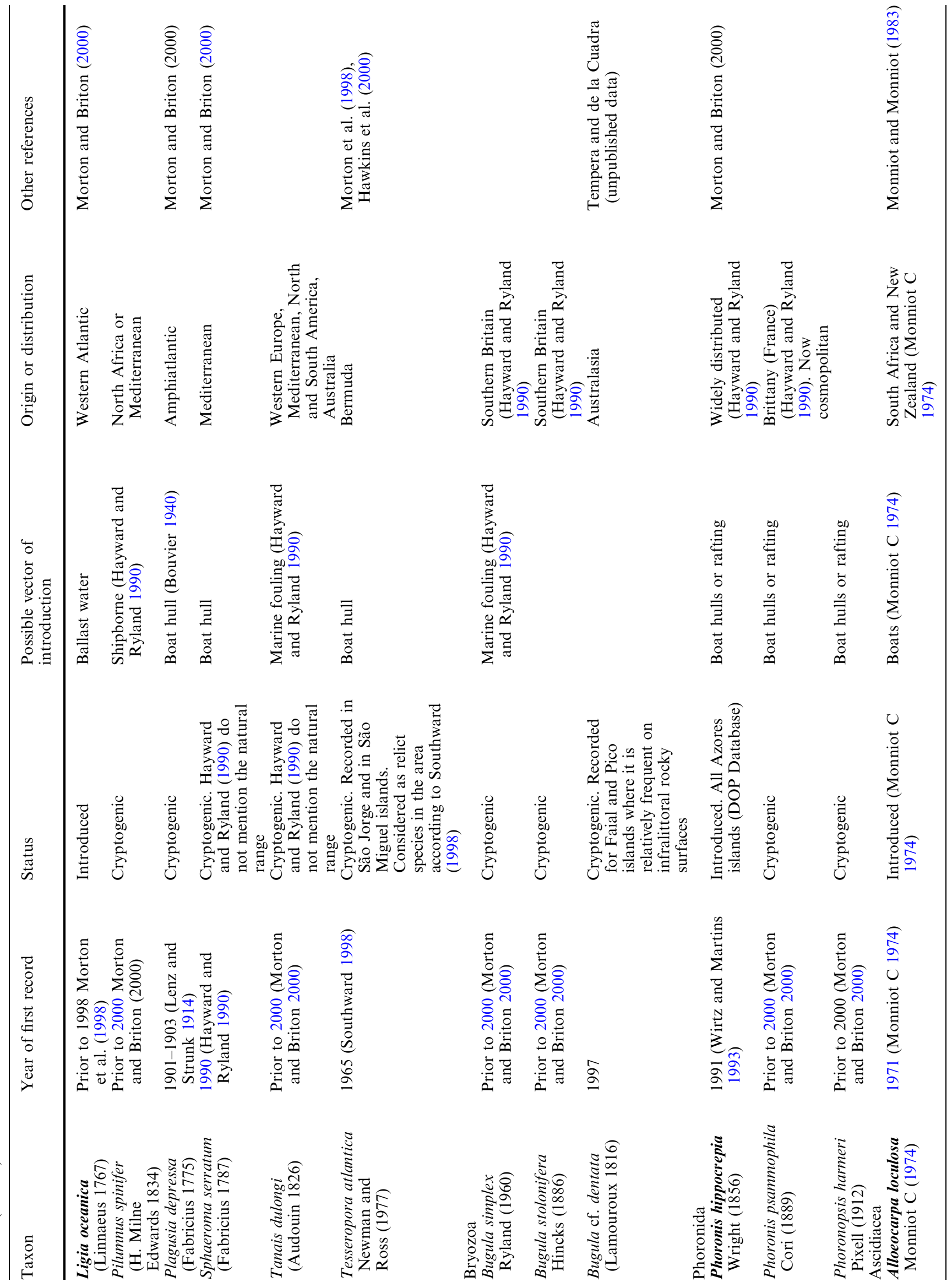




\begin{tabular}{|c|c|c|c|c|c|c|c|c|c|}
\hline 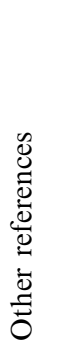 & & 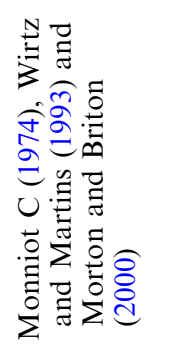 & 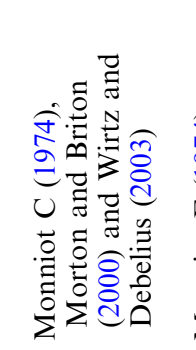 & 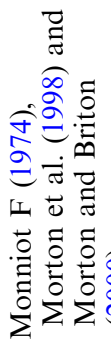 & 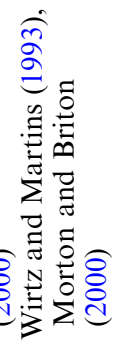 & 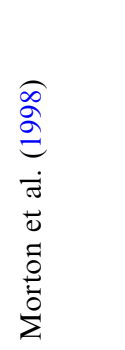 & \multicolumn{3}{|c|}{ 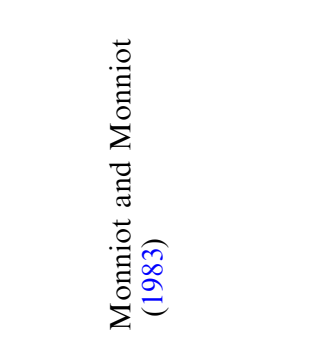 } \\
\hline 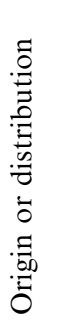 & 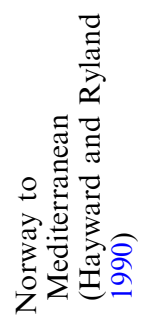 & 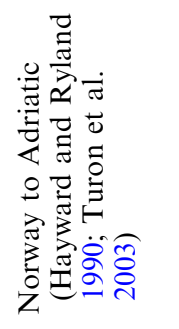 & 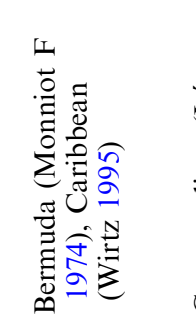 & 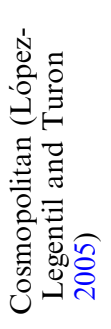 & 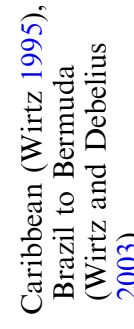 & 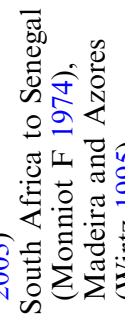 & 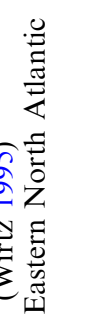 & 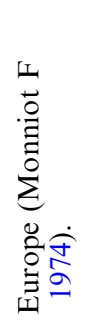 & 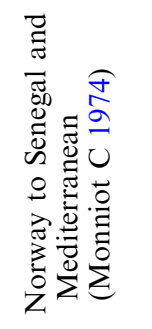 \\
\hline 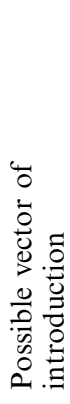 & 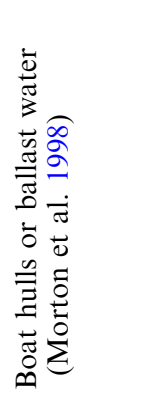 & 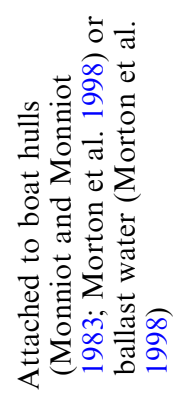 & 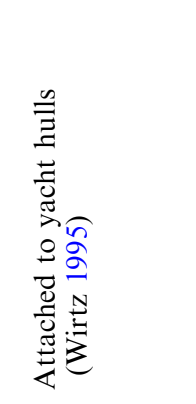 & & 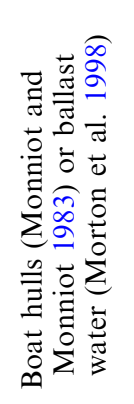 & 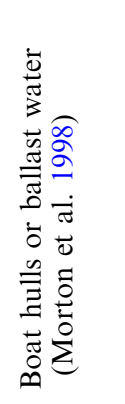 & 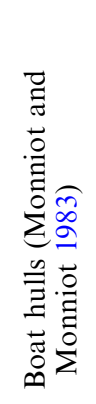 & 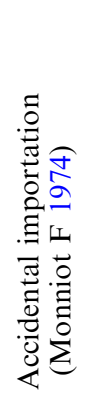 & 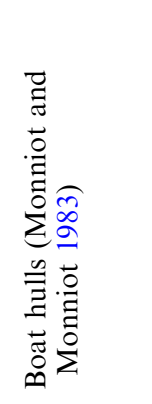 \\
\hline $\begin{array}{l}\sum_{\tilde{E}}^{n} \\
\text { in }\end{array}$ & 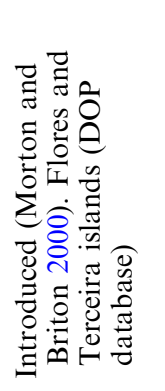 & 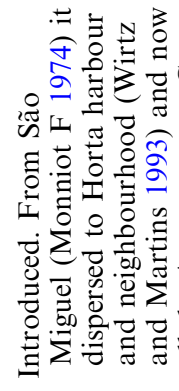 & 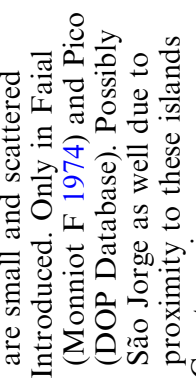 & 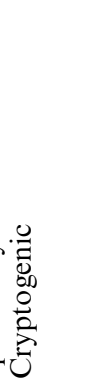 & 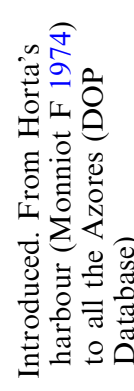 & $\begin{array}{l}0.0 \\
0 \\
0\end{array}$ & 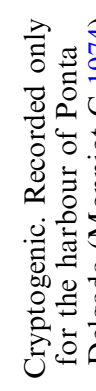 & 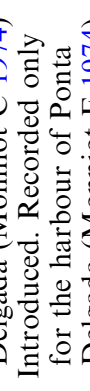 & 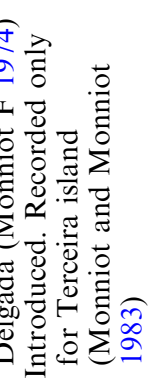 \\
\hline 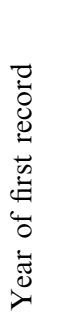 & 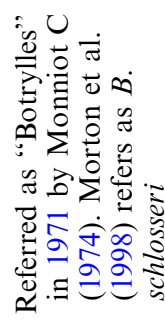 & 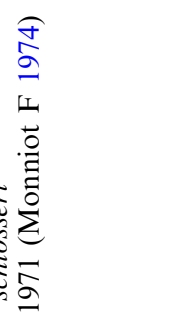 & 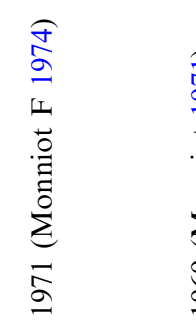 & 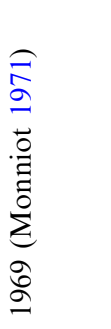 & 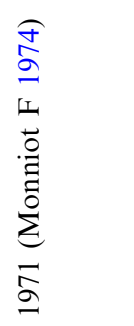 & 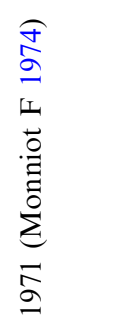 & 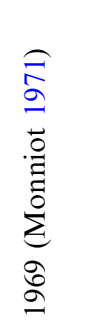 & 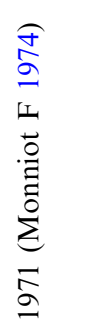 & 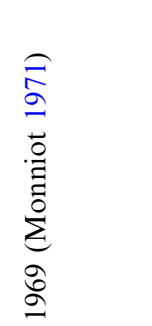 \\
\hline$\underline{x}$ & 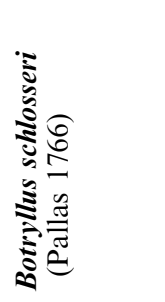 & 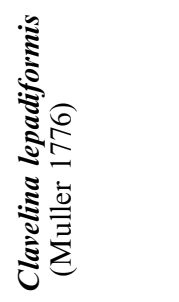 & 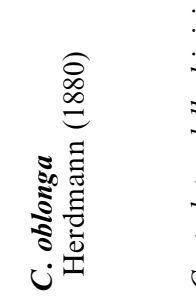 & 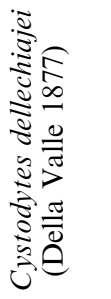 & 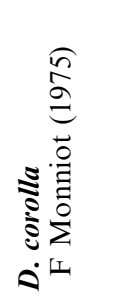 & 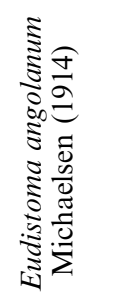 & 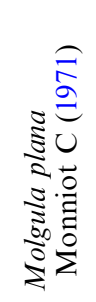 & 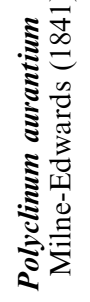 & 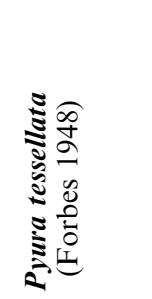 \\
\hline
\end{tabular}


to clarify the origin of several species (e.g., Sabella spallanzanii in Morton and Britton 2000).

The genus Caulerpa, mentioned by Lowe et al. (2000) as a particularly invasive taxon, is present in the Azores. Several healthy mats of $C$. webbiana have now been identified outside Horta harbour and deserve special attention in future studies.

The bivalve Mytilus edulis has been occasionally reported for the Azores. Ávila et al. (1998) reported small populations inside the harbour of Ponta Delgada (São Miguel island) but recent surveys did not find live specimens (Avila 2005). Transient mussels were also found in Santo Cristo Lagoon, São Jorge island (Morton et al. 1998). This species arrives at the Azores with floating objects (e.g., adrift floats with ropes hanging on the water column). Shells found inside harbours may have been discarded after meals. No self-sustaining populations have ever been recorded and this species is not considered to have established.

Several species in the northern hemisphere display a northward expansion of their distribution area due to the increase of water temperature (Elliot 2003; Perry et al. 2005). For the Azores, this seems to be the case for the fish species Canthigaster capistrata according to Wirtz (2005). Scorpaena canariensis is a rare species in the Azores and Wirtz (2005) admits this as a possible case of a northward expansion. As no direct human vector seems to be applicable to these species, they were not considered as introduced.

Other coastal fish species, such as Chaetodon sedentarius, Aluterus monoceros, Fistularia petimba (Santos et al. 1997; Wirtz 2005; Afonso et al. unpublished data) and Mycteroperca phenax (Morato et al. 2004) occur occasionally in the Azores but no stable populations seem to have established. Apparently, the same is applicable to the hydroid $V$. halecioides which was recorded only once in the Azores, in Horta's marina at the island of Faial (Cornelius 1992). In this particular case, more surveying should be carried out.

Acknowledgements FC and AC are financed by the EXOCET project (FP6-GOCE-CT-2003-505342). FT is financed by a grant (ref. SFRH/BD/12885/2003) from the Fundação para a Ciência e a Tecnologia. SA is financed by grant SFRH/BPD/22913/2005 (FCT) of the Portuguese government. "DOP Database" has been funded by the research projects MAROV (PDCTM/P/MAR/ 15249/1999), MARÉ (Life Natureza B4-3200/98-509), OGAMP (Interreg IIIB-MAC/4.2/A2) and MARMAC (Interreg 03/MAC/ 4.2/A1). Our thanks to Helen Rost Martins and Filipe Mora Porteiro for the valuable sharing of information and literature. Special thanks are due to the marine biologists Rogério Ferraz, Jorge Fontes, Pedro Afonso, Ana Meirinho, Luís Barcelos, Vanessa Santos, Vera Guerreiro and Pedro Frade, the database operator Ricardo Medeiros and Emanuel Arand for the German translations; to Prof. Dr. António Frias Martins for sharing information about records and condition of Truncatella subcylindrica; to Dr. Carlos de la Cuadra (University of Seville) for the collaboration in the identification of bryozoans. Thanks are due to the editor and two anonymous referees, who have immensely contributed to the improvement of this manuscript. The authors acknowledge the support by the MARBEF Network of Excellence "Marine Biodiversity and Ecosystem Functioning" which is funded in the Community's Sixth Framework Programme (contract no.
GOCE-CT-2003-505446). This publication has the contribution number of MPS-06012 of MarBEF.

\section{References}

Ardré F, Boudouresque C-F, Cabioc'h J (1974) Présence remarquable du Symphocladia marchantioides (Harvey) Falkenberg (Rhodomélacées, Céramiales) aux Açores. Bull de Soc Phycologique de Fr 19:178-182

Athanasiadis A, Tittley I (1994) Antithamnioid algae (Rhodophyta, Ceramiaceae) newly recorded from the Azores. Phycologia 33(2):77-80

Ávila SP (2000) Shallow-water marine molluscs of the Azores: bio-geographical relationships. Arquipélago-Life Mar Sci (Suppl 2, Part A):99-131

Ávila SP (2003) The littoral molluses (Gastropoda, Bivalvia and Polyplacophora) of São Vicente, Capelas (São Miguel island, Azores): ecology and biological associations to algae. Iberus 21(1):11-33

Ávila SP (2005) Processos e Padrões de Dispersão e Colonização nos Rissoidae (Mollusca: Gastropoda) dos Açores, $x+329$ pp. PhD Thesis, Universidade dos Açores, Ponta Delgada

Ávila SP, Azevedo JMN, Gonçalves JM, Fontes J, Cardigos F (1998) Checklist of the shallow-water marine molluscs of the Azores: 1-Pico, Faial, Flores and Corvo islands. Açoreana $8(4): 487-523$

Ávila SP, Azevedo JMN, Gonçalves JM, Fontes J, Cardigos F (2000) Checklist of the shallow-water marine molluscs of the Azores: 2-São Miguel island. Açoreana 9(Suppl 2, Part A):139-173

Baker IH (1967) Coelenterates and Cirripedia. In: Final report Published by Chelsea College Azores expedition (July-October 1965). Chel-sea College of Science and Technology, University of London, pp 39-47

Barrois T (1888) Catalogue des crustacés marins recueillis aux Açores durant les mois d'Août et Septembre 1887. Imprimerie Le Bigot Frères, Lille, p 106

Bax N, Williamson A, Aguero M, Gonzalez E, Geeves W (2003) Marine invasive alien species: a threat to global biodiversity. Mar Policy 27:313-323

Boudouresque CF, Verlaque M (2002) Biological pollution in the Mediterranean Sea: invasive versus introduced macrophytes. Mar Pollut Bull 44:32-38

Bouvier E-L (1940) Faune de France 37: Décapodes marcheurs. Librarie de la Faculte des sciences. Published by Lechevalier, Paris, p 404

Carlton JT (1996) Biological invasions and cryptogenic species. Ecology 77:1653-1655

Chapman G, Dales RP (1954) Aspects of the fauna and flora of the Azores. II. Polychaeta. Ann Mag Nat Hist 12(7):678-683

Chualain FN, Maggs CA, Saunders GW, Guiry MD (2004) The invasive genus Asparagopsis (Bonnemaisoniaceae, Rhodophyta): molecular systematics, morphology, and ecophysiology of Falkenbergia isolates. J Phycol 40:1112-1126

Coles SL, DeFelice RC, Eldredge LG, Carlton JT (1999) Historical and recent introductions of non-indigenous marine species into Pearl Harbour, Oahu, Hawaiian Islands. Mar Biol 135(1):147-158; DOI: 10.1007/s002270050612

Cornelius P (1992) The Azores hydroid fauna and its origin, with discussion of rafting and medusa suppression. ArquipélagoLife Mar Sci 10:75-100

Drouët H (1861) Elements de la Faune Açoréene. J.B. Baillière \& Fils Libraires de L'Academie de Médecine, Paris, pp 245

Dollfus A (1888) Troisième campagne de «l'Hirondelle », 1887. Sur quelques crustacés isopodes du littoral des Açores. Bull Soc Zool Fr 13:35-36

Elliot M (2003) Biological pollutants and biological pollution-an increasing cause for concern. Mar Pollut Bull 46:275-280

França Z, Cruz JV, Nunes JC, Forjaz VH (2003) Geologia dos Açores: uma perspectiva actual. Açoreana 10(1):11-140 
Gruvel A (1920) Cirripèdes. Résultats des Campagnes Scientifiques Accomplies sur son Yacht par Albert 1er. Prince Souverain de Monaco 53:1-88

Haroun R, Gil-Rodríguez MC, Wildpret de la Torre W (2003) Plantas Marinas de las Islas Canarias. Canseco Editores SL, Talavera de la Reina, pp 319

Hawkins SJ, Corte-Real HBSM, Pannacciulli FG, Weber LC, Bishop JDD (2000) Thoughts on the ecology and evolution of the intertidal biota of the Azores and other Atlantic islands. Hydrobiologia 440:3-17

Hayward PJ, Ryland JS (1990) The marine fauna of the British Isles and North-West Europe, vol 2. Oxford University Press, Oxford

Knight-Jones P, Knight-Jones EW, Buzhinskaya G (1991) Distribution and interrelationships of northern spirorbid genera. Bull Mar Sci 48(2): 189-197

Kooistra WHCF, Stam WT, Olsen JL, Hoek C (1992) Biogeography of Cladophoropsis membranacea (Chlorophyta) based on comparisons of nuclear rDNA ITS sequences. J Phycol 28:660668

Lawson GW, Norton TA (1971) Some observations on the littoral and sublittoral zonation of Teneriffe (Canary Isles). Bot Mar 14:116-120

Lebouché A-M (1957) Observations sur l'écologie et sur la composition glucidique de Caulacanthus ustulatus. Bull C Étu Rech Sci Biarritz 1:397-399

Lenz H, Strunk K (1914) Die Dekapoden der Deutschen SüdpolarExpedition 1901-1903. I. Brachyuren und Macruren mit Ausschluss der Sergestiden. Deutsche Südpolar-Exped Zool 15(7):257-345

López-Legentil S, Turon X (2005) How do morphotypes and chemotypes relate to genotypes? The colonial ascidian Cystodytes (Ascidiacea: Polycitoridae). Zool Scr 34:3-14

Lowe S, Browne M, Boudjelas S, De Poorter M (2000) 100 of the world's worst invasive alien species. A selection from the global invasive species database. Published by ISSG as special lift-out in Aliens 12, December 2000, pp 12

MacAndrews R (1856) Report on the marine testaceous Mollusca of the North-east Atlantic and neighbouring Seas, and the physical conditions affecting their development. In: Report of the twenty-sixth meeting of the British association for the advancement of science, held in Cheltenham, pp 101-158

Monniot C (1971) Quelques ascidies infralittorales de São Miguel. Bull Mus Natn Hist nat 2 sér 42(6):1200-1207

Monniot C (1974) Ascidies littorales et bathyales récoltées au cours de la campagne Biaçores: Phlébobranches et Stolidobranches. Bull Mus Natn Hist nat 3 sér 251(173):1287-1324

Monniot C, Monniot F (1983) Navigation ou courants? La colonization des Açores et des Bermudes par les ascidies (Tuniciers benthiques). C R Soc Biogéogr 59(1):53-58

Monniot F (1974) Ascidies littorales et bathyales récoltées au cours de la campagne Biaçores: Aplousobranches. Bull Mus Natn Hist nat 3 sér 251(173):1287-1325

Morato T, Afonso P, Carlin JL (2004) First record of scamp, Mycteroperca phenax, in the north-eastern Atlantic. J Mar Biol Ass UK 84:281-282

Morton B (1967) Malacological report. In: Final report Published by Chelsea College Azores expedition (July-October 1965). Chelsea College of Science and Technology, University of London, pp 30-37

Morton B, Britton JC (2000) Origins of the Azorean intertidal biota: the significance of introduced species, survivors of chance events. Arquipélago-Life Mar Sci (Suppl 2, Part A):29-51

Morton B, Britton JC, Martins AMF (1998) Costal ecology of the Açores. Sociedade Afonso Chaves, Ponta Delgada, pp 249

Moss D (1992) A summary of the Porifera collected during expedition Azores 1989. Arquipélago-Life Mar Sci 10:45-54

Neto AI (1994) Checklist of the benthic marine macroalgae of the Azores. Arquipélago-Life Mar Sci 12A:15-34

Neto AIMA (1997) Studies on algal communities of São Miguel, Azores. PhD thesis. Universidade dos Açores, Ponta Delgada, pp 309
Neto AI (2000a) Observations on the biology and ecology of selected macroalgae from the littoral of Sao Miguel (Azores). Botanica Marina 43(5):483-498

Neto AI (2000b) Ecology and dynamics of two intertidal algal communities on the littoral of the island of Sao Miguel (Azores). Hydrobiologia 432(1-3):135-147

Neto AI, Baldwin HP (1990) Algas marinhas do litoral das Ilhas do Corvo e Flores. Relatórios e Comunicaçöes do Departamento de Biologia, 18:103-111

Neto AI, Fralick RA, Baldwin HP, Hehre (1990) Algas marinhas do Litoral de Santa Maria. Santa Maria e Formigas/1990, Relatório, Relatórios e Comunicaçöes do Departamento de Biologia, 19:33-42

Nobre A (1930) Materiais para o estudo da Fauna dos Açores. Instituto de Zoologia da Universidade dos Açores, 108pp

Nordsieck F (1969) Die europäischen Meeresmuscheln (Bivalvia). Gustav Fischer Verlag, Stuttgart, pp 256

Nyberg CD, Wallentinus I (2004) Can species traits be used to predict marine macroalgal. Biol Invasions 7(2):265-279

Poppe GT, Goto Y (1991) European seashells, vol I. Verlag Christa Hemmen, pp 352

Poppe GT, Goto Y (1993) European seashells, vol II. Verlag Christa Hemmen, pp 221

Perry AL, Low PJ, Ellis JR, Reynolds JD (2005) Climate change and distribution shifts in marine fishes. Science 308(5730):19121915

Rodríguez RG, Sánchez JMP (1997) Moluscos Bivalvos de Canarias. Ediciones del Cabildo Insular de Gran Canaria, Las Palmas de Gran Canaria, p 425

Rueness J, Rueness EK (2000) Caulacanthus ustulatus (Gigartinales, Rhodophyta) from Brittany (France) is an introduction from the Pacific Ocean. Cryptogam Algol 21:355-363

Ruesink JL, Lenihan HS, Trimble AC, Heiman KW, Micheli F, Byers JE, Kay MC (2005) Introduction of non-native oysters: ecosystem effects and restoration implications. Annu Rev Ecol Evol Syst 36:643-689

Santos RS, Hawkins S, Monteiro LR, Alves M, Isidro EJ (1995) Marine research, resources and conservation in the Azores. Aquat Conserv Mar Freshw Ecosyst 5(4):311-354

Santos RS, Porteiro F, Barreiros JP (1997) Marine fishes of the Azores. Annotated checklist and bibliography. ArquipélagoLife Mar Sci 25(Suppl 1):242

Schmidt OC (1931) Die marine vegetation der Azoren in ihren Grundzuegen dargestellt. Bibl Bot 102:1-116

Silva A (2000) Impressões: Amêijoa talvez na baía da Praia da Vitória. J A União 31307:2-3

Southward AJ (1998) New observations on barnacles (Crustacea: Cirripedia) of the Azores region. Arquipélago- Life Mar Sci 16A:11-28

Tittley I, Neto AI (1994) Expedition Azores 1989: benthic marine algae (seaweeds) recorded from Faial and Pico. Arquipélago-Life Mar Sci 12A:1-13

Tittley I, Neto AI (1995) The marine algal flora of the Azores and its biogeographical affinities. Bol Mus Mun Funchal Sup 4:747766

Tittley I, Neto AI (2005) The marine algal (seaweed) flora of the Azores: additions and amendments. Botanica Marina 48(3):248-255

Tittley I, Neto A, Farnham W (1998) Marine algae of the island of Flores, Azores: ecology and floristics. Bol Mus Mun Funchal $5: 463-479$

Turon X, Tarjuelo I, Duran S, Pascual M (2003) Characterising invasion process with genetic data: an Atlantic clade of Clavellina lepadiformis (Ascidiacea) introduced into Mediterranean harbours. Hydrobiologia 503:29-35

Verlaque M, Afonso-Carrillo J, Gil-Rodríguez MC, Durand C, Boudouresque CF, Le Parco Y (2004) Blitzkrieg in a marine invasion: Caulerpa racemosa var. cylindracea (Bryopsidales, Chlorophyta) reaches the Canary Islands (north-east Atlantic). Biological Invasions 6:269-281

Wirtz P (1995) Unterwasserführer Madeira, Kanaren, Azoren. Naglschmid, Stuttgart, p 247 
Wirtz P (2005) Neue Fische für Madeira und die Azoren. Das Aquarium 430:48-53

Wirtz P, Debelius H (2003) Mediterranean and Atlantic invertebrate guide. ConchBooks, Hackenheim, pp 305

Wirtz P, Martins HR (1993) Notes on some rare and little known marine invertebrates from the Azores, with a discussion of the zoogeography of the region. Arquipélago-Life Mar Sci 11A:55-63

Yoneshigue Y (1985) Taxonomie et Ecologie des Algues Marines dans la region de Cabo Frio (Rio de Janeiro, Bresil). Univ. d'Aix- Marseille, France, pp 454
Zibrowius H, Bianchi CN (1981) Spirorbis marioni et Pileolaria berkeleyana, Spirorbidae exotiques dans les ports de la Mediterranée nord-ocidentale. Rapp et proc-verb reun Commis Int Explor Sci Mer Mediterr Monaco 27(2):163-164

Zuccarello GC, West JA, Rueness J (2002) Phylogeography of the cosmopolitan red alga Caulacanthus ustulatus (Caulacanthaceae, Gigartinales). Phycol Res 50:163-172

Zullo VA (1992) Balanus trigonus Darwin (Cirripedia, Balaninae) in the Atlantic basin: an introduced species? Bull Mar Sci 50(1):66-74 